\title{
The productivity of row crops with minimized and zero tillage in the conditions of irrigation of the South of Ukraine
}

\author{
Malyarchuk M. ${ }^{1}$, Reznichenko N. ${ }^{2}$, Malyarchuk A. ${ }^{3}$, Kotelnikov D. ${ }^{4}$ \\ 1, 3, 4 Institute of Irrigated Agriculture of NAAS \\ Nadnepryanskiy vil., Kherson, 73483, Ukraine \\ ${ }^{2}$ Askaniiska state agricultural research station of Institute of Irrigated Agriculture of NAAS \\ 40-richcha Peremohy Str., Tavrichanka vil., Kakhovsky region, Kherson oblast, 74862, Ukraine

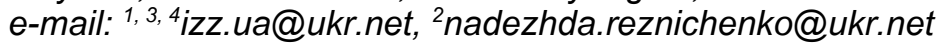 \\ ORCID: ${ }^{1} 0000-0002-0150-6121,{ }^{2} 0000-0002-5741-6379,{ }^{3} 0000-0001-5845-269 x,{ }^{4} 0000-0002-8889-8841$
}

\begin{abstract}
Goal. To determine the productivity of 4-field crop rotation with minimized and zero main tillage and organomineral fertilizer systems using post-harvest residues and green manures in the conditions of irrigation of the South of Ukraine. Methods. Field, quantitative, visual, laboratory, computational, mathematical, and statistical methods using generally accepted in Ukraine methods and guidelines. Results. The data are given of experimental researches of formation of productivity of cultures of 4-field row crop rotation at various basic cultivation of soil and fertilizers on the irrigated lands in a zone of action of the Kakhovka irrigation system. It was found that the highest productivity was provided by crop rotation on the background of different depth chisel main tillage, which under the organomineral fertilizer system using after-harvest residues and green manure on the background of different doses of mineral fertilizers provided $8.06-9.10 \mathrm{t} / \mathrm{ha}$ of grain units. The use of green manure for fertilizer helped to increase crop rotation productivity with differentiated and shallow $(12-14 \mathrm{~cm}$ ) single-depth disc loosening by $6.5 \%$, with different depth chisel - by 7.4 , for zero - by $9.2 \%$. Conclusions. On dark chestnut soil in the conditions of irrigation of the South of Ukraine, the highest productivity was provided by row crop rotation with different depths of shelfless main cultivation on the background of organomineral fertilizer system with N120P40 application and use for fertilizing of by-products of crop rotation and green manure.
\end{abstract}

Key words: basic tillage, yield, fertilizer system, crop rotation, green manure, after-harvest residues. DOI: https://doi.org/10.31073/agrovisnyk202101-08

Stability of production of grain in the Steppe area of Ukraine is largely determined by the resources of soil moisture. In addition during the last years there is worsening of the aquatic mode of soils from the increase of droughtyness of climate, inefficient structure of sowing areas, crop rotations and systems of basic tillage of soil. In modern terms considerable part of agricultural producers in the area of distribution of black earth soils pass to the minimized and no-till systems of basic tillage [1-3].

At the same time on livery soils, heavy and middle-loamy of grain-size distribution, that embrace greater part of the irrigated lands of south part of the Steppe area of Ukraine, the closeness of addition rises at the protracted application of the minimized and no-till systems of basic tillage, porosity and permeability to water go down to the critical limits which air is violated from, aquatic and nourishing modes of soils and the productivity of crop rotations [4-6]

By application of corresponding agrotechnical measures on the basis of application ecologically of safe crop rotations with complete or partial replacement of mineral fertilizers on organic as side products and siderates in the after harvesting and post-harvest sowing it is possible to improve effective fertility of soils and create terms for realization of the genetically conditioned potential of the productivity of agricultural cultures [7, 8].

Also, it is necessary to mark that an important value acquires the account of charges of resources on unit of the got products of every culture of crop rotation. First of all positively the complex of agrotechnical factors influences on plants is irrigation, fertilizers and tillage of soil, that contingently the increase of intensity of processes of products, and as a result is a receipt of maximal level of the productivity and quality of products [8-11].

The purpose of researches consisted in establishment of influence of minimum and no-till tillage of soil on the productivity of short crop rotation in the conditions of irrigation of south of Ukraine.

Materials and methods of researches. During realization of researches used confessedly methods: the field, laboratory, mathematical, comparatively-calculation.

Stationary experience on establishment of efficiency of the minimized and no-till technologies of basic tillage of soil is stopped up in 4-fields row crop rotation in autumn in 2007 on Askanian State Agricultural Research Station of the Institute of Irrigated Agriculture of NAAS of Ukraine which is located in the area of action of the Kakhovka irrigatory system. On experimental research were put four systems of basic tillage of soil. For control the confessedly for the irrigated lands system of the differentiated basic tillage of soil at which during the rotary press of crop rotation tillage of soil with the turn of layer under the cultivated cultures alternates with the plowless shallow loosening under grain-growing cereals is taken. The single-depth shallow $(12-14 \mathrm{~cm})$ (disk) system of basic tillage was used in the second variant. In the third variant plowless on 
different depth shallow with the depth of loosening from $23-25$ to $28-30 \mathrm{~cm}$. The system of no-till was investigated In a fourth variant.

Research on determination of efficiency of sideration due to the post-harvesting sowing of mustard sarepta is conducted during 2016-2019 on a background three organic-mineral systems of fertilizer with doses - $N_{120} P_{40}$ without siderate; $\mathrm{N}_{120} \mathrm{P}_{40}+$ siderate; $\mathrm{N}_{90} \mathrm{P}_{40}+$ siderate; $\mathrm{N}_{105} \mathrm{P}_{40}+$ siderate (table 1$)$.

1. Stationary experiment scheme on the study of methods, depth and systems of basic soil tillage

\begin{tabular}{|c|c|c|c|c|c|}
\hline \multirow{2}{*}{\multicolumn{2}{|c|}{$\begin{array}{l}\text { Basic soil tillage system } \\
\qquad(\text { factor } A)\end{array}$}} & \multicolumn{4}{|c|}{ Depth and method of basic tillage (cm) } \\
\hline & & corn on grain & $\begin{array}{c}\text { winter barley } \\
\text { mustard on siderate }\end{array}$ & soybean & $\begin{array}{l}\text { wheat winter + } \\
\text { mustard on siderate }\end{array}$ \\
\hline 1 & Differentiated (control) & $28-30(p)$ & $12-14(d)$ & $28-30(p)$ & $12-14(d)$ \\
\hline 2 & $\begin{array}{c}\text { Plowless single-depth } \\
\text { shallow }\end{array}$ & $12-14$ (ch) & $12-14(d)$ & $12-14$ (ch) & $12-14(d)$ \\
\hline 3 & $\begin{array}{l}\text { Plowless on different } \\
\text { depth shallow }\end{array}$ & 28-30 (ch) & $23-25$ (ch) & $28-30$ (ch) & 23-25 (ch) \\
\hline 4 & No-till & (n) & (n) & $(n)$ & (n) \\
\hline
\end{tabular}

Note: $\mathrm{p}$ - plowing, $\mathrm{d}$ - disk tillage, ch - a chisel loosening, $\mathrm{n}$ - no-till.

Mustard on siderate was sown by special seeder for sowing in preliminary untilled soil after mowing of winter grain-crops and shelling of stubble of predecessor by disk harrows (except variants, where investigated efficiency of no-till).

The soil moisture during the vegetation of cultures of crop rotation was kept up at the level of $70 \%$ of the soil water-holding capacity in the layer of soil 0-50 cm. Gobbing of the field experiments and realization of the field researches was executed in accordance with confessedly methods, manuals and methodical recommendations [12, 13].

Results of researches. It is set as a result of experimental researches, that on the average for four years, closeness of addition of layer of soil a $0-40 \mathrm{~cm}$ was higher on $0,01-0,04 \mathrm{~g} / \mathrm{cm}^{3}$ in a variant without a sideration as compared to variants, where siderate was used. A no-till system of basic tillage had a substantial influence on the closeness of addition. So, if in the variant of the differentiated system basic tillage (control) with bringing of dose of mineral fertilizers of $\mathrm{N}_{120} \mathrm{P}_{40}+$ siderate closeness of addition of layer of soil a $0-40 \mathrm{~cm}$ on the average for four years made a $1,19 \mathrm{~g} / \mathrm{cm}^{3}$, then in the variant of a no-till system this index increased to $1,25 \mathrm{~g} / \mathrm{cm}^{3}, \mathrm{or}$ on $5,04 \%$. In a variant with the same dose of bringing of mineral fertilizers, but without the siderate indexes of closeness of addition were some higher and a difference between the differentiated and no-till system of basic tillage arrived at $6,7 \%$.

On the indexes of porosity of layer of soil a $0-40 \mathrm{~cm}$ of substantial difference between the variant of the differentiated system of basic tillage (control) and plowlesss single-depth shallow and different depth it is not set

The substantial decline of porosity as compared to control is marked only in the variant of the system of a no-till tillage with an index on the siderate background of $52,11 \%$, and in a variant without siderate - 50,96\%, that less than on control accordingly on 4,2 and 5,7 relative percent (table 2 ).

2. The bulk density and porosity of layer of soil a $0-40 \mathrm{~cm}$ at the beginning of vegetation of cultures of crop rotation at the different systems of basic tillage and sideration, $\mathrm{g} / \mathrm{cm}^{3}, \mathrm{AV}$ for 2016-2019

\begin{tabular}{|c|c|c|c|}
\hline Basic soil tillage system (factor & System of fertilizer (factor of $\mathrm{A}$ ) & Bulk density, g/cm ${ }^{3}$ & Porosity, \% \\
\hline \multirow{2}{*}{$\begin{array}{c}\mathrm{B} \text { ) } \\
\text { Differentiated (control) }\end{array}$} & $\mathrm{N}_{120} \mathrm{P}_{40}+$ siderate & 1,19 & 54,41 \\
\cline { 2 - 4 } & $\mathrm{N}_{120} \mathrm{P}_{40}$ & 1,20 & 54,02 \\
\hline \multirow{2}{*}{ Plowless single-depth shallow } & $\mathrm{N}_{120} \mathrm{P}_{40}+$ siderate & 1,21 & 53,64 \\
\cline { 2 - 4 } & $\mathrm{N}_{120} \mathrm{P}_{40}$ & 1,22 & 53,26 \\
\hline \multirow{2}{*}{$\begin{array}{c}\text { Plowless on different depth } \\
\text { shallow }\end{array}$} & $\mathrm{N}_{120} \mathrm{P}_{40}+$ siderate & 1,16 & 55,56 \\
\cline { 2 - 4 } & $\mathrm{N}_{120} \mathrm{P}_{40}$ & 1,20 & 54,02 \\
\hline \multirow{2}{*}{ No-till } & $\mathrm{N}_{120} \mathrm{P}_{40}+$ siderate & 1,25 & 52,11 \\
\cline { 2 - 4 } & $\mathrm{N}_{120} \mathrm{P}_{40}$ & 1,28 & 50,96 \\
\hline
\end{tabular}


Changes of indexes of closeness of addition and porosity under the action of the systems of basic tillage and fertilizer influenced on the processes of absorption, accumulation and filtration of water. On the average for years researches speed of absorption of water at the three-hour display of determinations was the greatest at the plowless on different depth shallow system basic tillage and on a background a sideration her indexes made a $4,59 \mathrm{~mm} / \mathrm{min}$, that higher, than at the differentiated system of basic tillage on $15,0 \%$. On a background without bringing a siderates difference between these variants was some below and 7,4 \%.

At the system of a no-till indexes of permeability to water were most subzero and on a siderate background were 2,71 , and on a background without siderate $2,15 \mathrm{~mm} / \mathrm{min}$, that below, than at the differentiated system of basic tillage (control) on 32,1 and 38,8\% accordingly (table 3 ).

3. Water-permeability of soil at different methods and depth of soil tillage and sideration (AV for 20162019), $\mathrm{mm} / \mathrm{min}$

\begin{tabular}{|c|c|c|}
\hline Basic soil tillage system (factor $\mathrm{A}$ ) & System of fertilizer (factor of $\mathrm{B}$ ) & $\begin{array}{c}\text { Water-permeability, } \\
\mathrm{mm} / \mathrm{min}\end{array}$ \\
\hline \multirow{2}{*}{ Differentiated (control) } & $\mathrm{N}_{120} \mathrm{P}_{40}+$ siderate & 3,99 \\
\cline { 2 - 3 } & $\mathrm{N}_{120} \mathrm{P}_{40}$ & 3,51 \\
\hline \multirow{2}{*}{ Plowless single-depth shallow } & $\mathrm{N}_{120} \mathrm{P}_{40}+$ siderate & 3,95 \\
\cline { 2 - 3 } & $\mathrm{N}_{120} \mathrm{P}_{40}$ & 3,36 \\
\hline \multirow{2}{*}{ Plowless on different depth shallow } & $\mathrm{N}_{120} \mathrm{P}_{40}+$ siderate & 4,59 \\
\cline { 2 - 3 } & $\mathrm{N}_{120} \mathrm{P}_{40}$ & 3,77 \\
\hline \multirow{2}{*}{ No-till } & $\mathrm{N}_{120} \mathrm{P}_{40}+$ siderate & 2,71 \\
\cline { 2 - 3 } & $\mathrm{N}_{120} \mathrm{P}_{40}$ & 2,15 \\
\hline
\end{tabular}

Systems basic changing tillages of soil and fertilizer agrophysics properties, aquatic and airily-thermal the modes influenced on intensity of flowing of microbiological processes and material well-being of plants the ingredients of mineral feed.

On the average for four years of rotary press of crop rotation nitrification capacity of layer of soil a 0-40 $\mathrm{cm}$ under sowing of agricultural cultures was high enough in all variants basic tillage of soil. At the differentiated system (control) with ploughing under a corn on grain and soybean and shallow disk loosening under a wheat winter and barley maintenance of nitrates in the punched standards at the organic-mineral system of fertilizer with the use of siderate made $48,2 \mathrm{mg} / \mathrm{kg}$, and without bringing of siderate it was below on $14,1 \%$ and made $41,4 \mathrm{mg} / \mathrm{kg}$ of soil. At plowless - single-depth shallow and different systems of basic tillage the decline of nitrification capacity as compared to control on a siderate background attained 16,8 and $4,7 \%$, and on a background without bringing of siderate - 29,7 and $10,7 \%$ accordingly.

Most subzero the capacity of soil for formation of nitrates was formed at the system of no-till with indexes on a siderate background $28,6 \mathrm{mg} / \mathrm{kg}$ of soil, or on $40,7 \%$ below, than on control and on $14,7 \%$ higher, than without bringing of siderate.

Table of contents of mobile connections of phosphorus in the layer of soil a $0-40 \mathrm{~cm}$ on a siderate background in variants differentiated and different depth plowless systems of basic tillage was high with indexes 51,1 and $47,8 \mathrm{mg} / \mathrm{kg}$ of soil, and in the variant of shallow plowless and no-till their maintenance was at middle level and was 40,7 and $37 \mathrm{mg} / \mathrm{kg}$ of soil (Fig. 1)

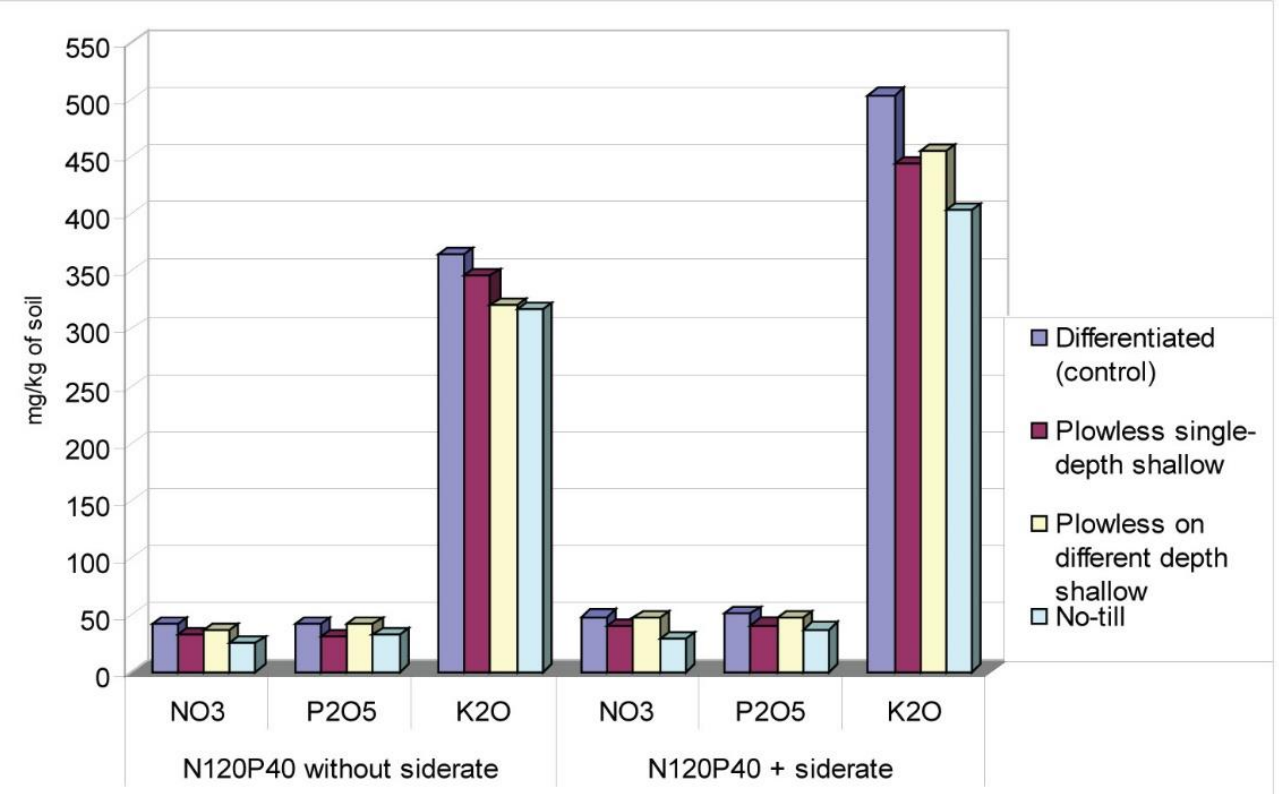

Fig. 1. Contents of basic ingredients of feed in the layer of soil a $0-40 \mathrm{~cm}, \mathrm{mg} / \mathrm{kg}$ of soil 
On a background without the use of mustard on siderate maintenance of connections of mobile phosphorus at differentiated and plowless systems of basic tillage went down on $22,4-23,8 \%$, and at no-till only on $10,9 \%$ at the general for all variants middle level of material well-being.

Material well-being of layer of soil a $0-40 \mathrm{~cm}$ by exchange potassium on the average for years experimental researches in sowing of cultures of crop rotation characterized by a high level on a siderate background and hesitated within the limits of a 403,0-503,8 $\mathrm{mg} / \mathrm{kg}$ of soil with the greatest indexes at differentiated and different depth plowless systems of basic tillage.

On a background without application siderate a maintenance of exchange potassium in soil was below on the variants of the systems of basic tillage on $21,4-29,6 \%$.

The got results of experimental researches testify that the changes of agrophysics properties and nourishing mode stipulated creation of different terms for a height and development of agricultural cultures and forming of harvest. Hereupon the productivity of cultures and productivity of crop rotation was formed by different

Only sowing in preliminary untilled soil, especially corn and soybean, resulted in the substantial decline of their productivity and productivity of crop rotation. It is also necessary to mark that at the differentiated system of basic tillage of soil and use on the fertilizer of siderate culture on a background the different doses of mineral fertilizers the productivity of crop rotation was formed at the level of 7,81-8,72 t/ha of grain-growing units.

At the shallow plowless loosening the productivity of crop rotation on the average for a rotary press was at the level of control with indexes on the systems of tillage and doses of fertilizers of 7,73-8,76 grain-growing units and application of no-till on a background all investigated systems of fertilizer, resulted in the decline of the productivity to $6,84-7,50$ t/ha of grain-growing units.

The greatest productivity calculating on one hectare of area of crop rotation was provided by a crop rotation on Plowless on different depth shallow system of basic tillage with the chisel loosening under all cultures, which depending on the doses of bringing of nitric fertilizers was formed within the limits of 8,06-9,10 t/ha of grain-growing units (table. 5).

5. Productivity of short crop rotation at the different systems of soil basic tillage and fertilizer (AV after 2016-2019), t/ha

\begin{tabular}{|c|c|c|c|c|c|c|c|c|}
\hline \multirow[t]{2}{*}{$\begin{array}{l}\text { Basic soil tillage } \\
\text { system }(A)\end{array}$} & \multirow[t]{2}{*}{ System of fertilizer (B) } & \multirow[t]{2}{*}{ 동 } & \multirow{2}{*}{ 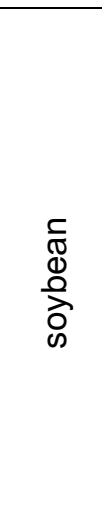 } & \multirow{2}{*}{ 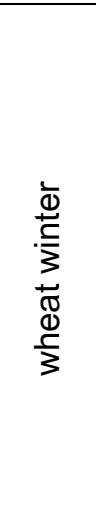 } & \multirow{2}{*}{ 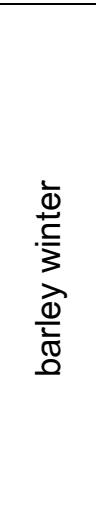 } & \multirow{2}{*}{ 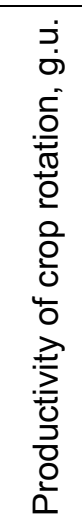 } & \multicolumn{2}{|c|}{ 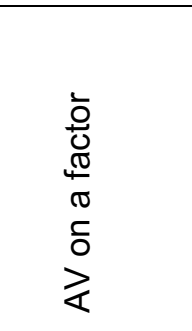 } \\
\hline & & & & & & & $\ll$ & $\varpi$ \\
\hline \multirow{4}{*}{$\begin{array}{l}\text { Differentiated } \\
\quad((\text { control })\end{array}$} & $\mathrm{N}_{90} \mathrm{P}_{40}+$ siderate & 11,87 & 4,73 & 7,85 & 6,80 & 7,81 & \multirow{4}{*}{8,21} & 7,61 \\
\hline & $\mathrm{N}_{105} \mathrm{P}_{40}+$ siderate & 12,64 & 5,12 & 8,17 & 7,04 & 8,24 & & 8,06 \\
\hline & $\mathrm{N}_{120} \mathrm{P}_{40}+$ siderate & 13,37 & 5,39 & 8,65 & 7,47 & 8,72 & & 8,52 \\
\hline & $\mathrm{N}_{120} \mathrm{P}_{40}$ & 12,51 & 4,97 & 8,14 & 6,56 & 8,05 & & 7,87 \\
\hline \multirow{5}{*}{$\begin{array}{l}\text { Plowless single- } \\
\text { depth shallow }\end{array}$} & $\mathrm{N}_{90} \mathrm{P}_{40}+$ siderate & 11,54 & 4,88 & 7,61 & 6,89 & 7,73 & \multirow{4}{*}{8,21} & \\
\hline & $\mathrm{N}_{105} \mathrm{P}_{40}+$ siderate & 12,48 & 5,39 & 8,03 & 7,10 & 8,25 & & \\
\hline & $\mathrm{N}_{120} \mathrm{P}_{40}+$ siderate & 13,24 & 5,49 & 8,64 & 7,67 & 8,76 & & \\
\hline & $\mathrm{N}_{120} \mathrm{P}_{40}$ & 12,43 & 4,88 & 8,19 & 6,97 & 8,12 & & \\
\hline & $\mathrm{N}_{90} \mathrm{P}_{40}+$ siderate & 12,39 & 4,92 & 7,86 & 7,06 & 8,06 & 8,49 & \\
\hline
\end{tabular}




\begin{tabular}{|c|c|c|c|c|c|c|c|}
\hline \multirow{3}{*}{$\begin{array}{l}\text { Plowless on } \\
\text { different depth } \\
\text { shallow }\end{array}$} & $\mathrm{N}_{105} \mathrm{P}_{40}+$ siderate & 13,25 & 5,40 & 8,20 & 7,25 & 8,52 & \\
\hline & $\mathrm{N}_{120} \mathrm{P}_{40}+$ siderate & 14,14 & 5,56 & 8,99 & 7,72 & 9,10 & \\
\hline & $\mathrm{N}_{120} \mathrm{P}_{40}$ & 13,10 & 5,08 & 8,22 & 6,74 & 8,28 & \\
\hline \multirow{4}{*}{ No-till } & $\mathrm{N}_{90} \mathrm{P}_{40}+$ siderate & 10,19 & 4,10 & 7,20 & 5,88 & 6,84 & \multirow{4}{*}{7,15} \\
\hline & $\mathrm{N}_{105} \mathrm{P}_{40}+$ siderate & 10,67 & 4,48 & 7,70 & 6,09 & 7,23 & \\
\hline & $\mathrm{N}_{120} \mathrm{P}_{40}+$ siderate & 10,95 & 4,67 & 8,00 & 6,38 & 7,50 & \\
\hline & $\mathrm{N}_{120} \mathrm{P}_{40}$ & 10,35 & 4,23 & 7,75 & 5,84 & 7,04 & \\
\hline
\end{tabular}

Organically-mineral system of fertilizer with the use on the fertilizer of after harvesting bits and pieces and bringing of mineral fertilizers the dose of $\mathrm{N}_{120} \mathrm{P}_{40}+$ siderate assisted the increase of the productivity of crop rotation as compared to without siderate background at differentiated and single-depth shallow systems of soil basic tillage on 7,7 and $7,4 \%$, at the system of different depth shallow on $9,1 \%$, at sowing of cultures in preliminary untilled soil - on $6,1 \%$.

\section{Conclusions}

On the irrigated lands of south of Ukraine the greatest productivity of the row crop rotation at the level of 9,10 t/ha of grain-growing units is provided by the organic-mineral system of fertilizer with bringing of mineral fertilizers the dose of $\mathrm{N}_{120} \mathrm{P}_{40}$ and side products of agricultural cultures and siderate on a background different depth shallow basic tillage of soil.

\section{References}

1. Vozhehova, R.A. (Ed.). (2014). Systemy zemlerobstva na zroshuvanykh zemliakh [Irrigated agriculture systems lands]. Kyiv: Ahrarna nauka. [In Ukrainian].

2. Tarariko, Yu.A. (2007). Formirovanie ustoychivykh agroekosistem [Forming sustainable agroecosystems]. Kiev: DIA. [In Russian].

3. Lymar, A.O. (2006). Intensyvni korotkorotatsiini zroshuvani sivozminy v systemi zemlerobstva Pivdennoho Stepu Ukrainy [Intensive short-rotation irrigated crop rotations in the agricultural system Southern Steppe of Ukraine]. Ukrainian Black Sea region agrarian science, 1, 8 - 15. [In Ukrainian].

4. Akbarov, O.R. (2006). K probleme razvitiya adaptivno-landshaftnoy sistemy oroshaemogo zemledeliya i povysheniya ego produktivnosti [On the problem of the development of an adaptive landscape system of irrigated agriculture and increasing its productivity]. New in water management, 4, 30 - 35. [In Russian].

5. Kovalenko, A.M. (2006). Ekolohichni aspekty pobudovy sivozmin korotkoi rotatsii na zroshuvanykh i nepolyvnykh zemliakh [Environmental aspects of crop rotations of short rotation on irrigated and nonirrigated lands]. Irrigated agriculture. Kherson: Ailant, 45, 52 - 55. [In Ukrainian].

6. Kisil, V.I. (2000). Biologicheskoe zemledelie v Ukraine: problemy i perspektivy [Biological agriculture in Ukraine: problems and prospects]. Kharkov: Shtrikh. [In Russian].

7. Arshad, M.A., Schnitzer, M., Angers, D.A., \& Ripmeester, J.A. (1990). Effects of till vs no-till on the quality of soil organic matter. Soil Biol. Biochem., 22(5), $595-599$.

8. Vysokoefektyvni systemy osnovnoho obrobitku gruntu: metod. rekom. Instytut zemlerobstva $i$ tvarynnytstva zakhidnoho rehionu NAAN (2010). [Highly efficient systems of basic tillage]. Institute of Agriculture and Animal Husbandry of the Western Region of NAAS. Lviv - Obroshyno. [In Ukrainian].

9. Filimonov, Yu.L., \& Nahaiev, V.M. (2011). Tekhnolohichni i ekonomichni aspekty efektyvnosti system obrobitku gruntu [Technological and economic aspects of tillage systems efficiency]. Bulletin of KhNAU. Economic Sciences Series, 4, 248 - 254. [In Ukrainian].

10. Tekhnolohiia nulovoho obrobitku gruntu nabyraie populiarnosti v Ukraini. (2013). [The technology of zero tillage is gaining popularity in Ukraine], $1-2$. [In Ukrainian].

11. Kovalenko, N.P. (2017). Naukovi osnovy stanovlennia ta rozvytku zemlerobstva v Ukraini [Scientific bases of formation and development of agriculture in Ukraine]. Bulletin of Agricultural Science. Special issue (May), 60 - 66. [In Ukrainian].

12. DSTU ISO 11272. (2001). Yakist gruntu. Vyznachannia shchilnosti skladennia na sukhu masu [DSTU ISO 11272 Soil quality. Determination of the density of addition to the dry mass]. [In Ukrainian].

13. DSTU 4362:2004. (2006). Yakist gruntu. Pokaznyky rodiuchosti gruntiv. Kyiv: Derzhspozhyvstandart Ukrainy [DSTU 4362: 2004. Soil quality. Indicators of soil fertility. Kyiv: Derzhspozhyvstandart Ukrainy]. [In Ukrainian].

14. DSTU ISO 14255:2005 (2005). Yakist gruntu. Vyznachennia nitratnoho azotu, amoniinoho azotu I zahalnoho rozchynnoho azotu $v$ povitriano-sukhykh gruntakh $z$ zastosuvanniam rozchynu khlorydu 
kaltsiiu dlia ekstrahuvannia [DSTU ISO 14255: 2005 Soil quality. Determination of nitrate nitrogen, ammonium nitrogen and total soluble nitrogen in air-dry soils using calcium chloride solution for extraction]. [In Ukrainian].

15. DSTU 4114-02 Grunty. (2002). Vyznachannia rukhomykh spoluk fosforu i kaliiu za modyfikovanym metodom Machyhina [DSTU 4114-02 Soils. Determination of mobile compounds of phosphorus and potassium by the modified Machigin method]. [In Ukrainian].

16. Vozhehova, R.A., Lavrynenko, Yu.O., \& Maliarchuk, M.P. (2014). Metodyka polovykh i laboratornykh doslidzhen na zroshuvanykh zemliakh [Methods of field and laboratory research on irrigated lands: a monograph]. Kherson: Hrin D.S. [In Ukrainian].

17. Ushkarenko, V.O., Vozhehova, R.A., \& Holoborodko, S.P. (2013). Statystychnyi analiz rezultativ polovykh doslidiv u zemlerobstvi [Statistical analysis of the results of field experiments in agriculture: a monograph]. Kherson: Ailant. [In Ukrainian]. 